\title{
Development of Virtual Lab Media to Improve Student's Critical Thinking Ability
}

\author{
Nur Fadhilah ${ }^{1, *}$ Derlina $^{2}$, Rahmatsyah $^{3}$ \\ 1,2,3 Postgraduate Physics Education, Medan State University \\ *Corresponding author. Email: nurfadhilah4893@gmail.com
}

\begin{abstract}
This study aims to generate media Virtual Lab on the basis of electrical materials that meet the criteria are valid instructional media, practical, and effective . The population in this study was the Airport Electrical Engineering class class XVII semester I, while the research subjects of the validity trial were Unimed physics lecturers and the subjects of the implementation of Virtual Lab learning media were the Airport Electrical Engineering class XVII, totaling 24 people and the Airport Electrical Engineering level III and XIV. 46 people. The procedure for developing Media Virtual Lab using the Research and Development Method initiated by Borg and Gall which consisted of research and information collecting, planning, developing preliminary forms of product, preliminary field testing, main product revision, main field testing, operational product revision, operational field testing, final product revision, and dissemination and implementation. The instruments used in this research are validity questionnaires to see the validity of the Virtual Lab media, lecturer and student response questionnaires to see the practicality of Virtual Lab media on basic electrical materials and pretest and posttest instruments to see the effectiveness of Virtual Lab Media . From the research results, it can be concluded that the Virtual Lab Media Development with an average value of $78.76 \%$ for media validation results while $78.86 \%$ for material expert validation results, both of which are categorized as quite valid and can be used but minor revisions. Practical response of Virtual Lab Media by lecturers with an average value of $86.1 \%$ which is categorized as very practical, while by students $82.94 \%$ for small groups and 77.33\% for large groups which are quite practical. The effectiveness of Media Virtual Lab shows N-Gain with a value of 0.61 which is considered effective on basic electrical materials .
\end{abstract}

Keywords: Virtual Lab , Capacity of critical thinking

\section{INTRODUCTION}

Media in physics learning can show real phenomena, are abstract, microscopic in size, and difficult words can be easily conveyed and interesting for students. The use of media to get direct experience can be done using actual objects in the form of practical tools in laboratory activities, or using media in the form of artificial objects resembling the real objects (Wahyuni et al, 2013).

The use of media in the learning process is classified into 4 categories, namely: human-based, printed, visual, audio-visual and computer-based (Arsyad, 2013). Learning media commonly used in schools are humanbased media, and prints. Learning using human-based media and textbooks makes students bored and uninterested and the material presented tends to be passive. Learning that is done by listening without doing anything else such as writing notes, the contribution of mastery of the material is only $5 \%$, followed by reading to $10 \%$ and studied with the help of audio-visuals to $30 \%$ (Wibowo et al, 2016).
The implementation of learning, especially in practicum, is expected to improve mastery of physics concepts, motivation, and skills in analyzing, processing data from practicum results and personal skills in using practicum tools. The implementation of learning should also involve and utilize existing information technology along with the current developments, be it the internet or offline and online simulations using certain software. Today's development requires students to be proficient in the use of IT in every learning process so that every student must have a computer or laptop to study.

One solution to the problem of implementing this practicum is to use learning media. Learning media is not only a solution to the problem of not implementing the practicum, but also can provide an understanding of the concept and repetition of the material. The alternative learning media in question can be in the form of a Virtual Lab. Virtual Labs that utilize IT use a computer program to simulate a series of experiments without carrying out experimental activities directly. Virtual Labs can strengthen practicum activities that cannot be implemented in real terms, meaning that this 
Virtual Lab can be an alternative practicum medium to replace real practicums if they cannot be implemented. This is in line with what Ismail (2016) said, namely Virtual Labs use computer programs to simulate a series of real experiments as a substitute for practicums that cannot be carried out directly. According to yuri, yumelda, and yolly (2020) Virtual Lab media has a high positive influence on student competence and is more effectively used for higher education levels.

This Virtual Lab can answer the limitations and implementation of practicum activities at school and on campus. Based on the above problems, it is necessary to realize the availability of learning media in the form of a Virtual Lab.

\section{METHOD}

This type of research is development research to produce Virtual Lab media products using Adobe Flash CS6. The research method used is the Research and Development Method initiated by Borg and Gall in 1986. This research will be carried out at the Medan Aviation Polytechnic Semester I of the 2019 academic year. The procedure and design of this research consists of 10 stages, namely: Research and information collecting, Planning, Develop preliminary form of product, Preliminary field testing, Main product revision, Main field testing, Operational product revision, Operational field testing, Final product revision, Dissemination and implementation. This study uses a validity questionnaire instrument to measure the feasibility of the Virtual Laboratory, to determine the practicality of the Virtual Laboratory media, lecturer and student response questionnaires are used, and to determine the effectiveness of learning media by measuring learning outcomes that can improve students' critical thinking skills by using the pretest and posttest given.

\section{RESULT AND DISCUSSION}

\subsection{Validation Results by material experts and media experts}

Virtual Lab media development assessment data by media experts obtained on average from the assessment of aspects of appearance, programming, usability, and language aspects of 3 validators, namely $78.76 \%$ with a fairly valid level of validity with categories that can be used but minor revisions and has been worthy of testing. try it on a limited scale in the field as shown in the graphic below

\section{Validation Results by Media Experts}

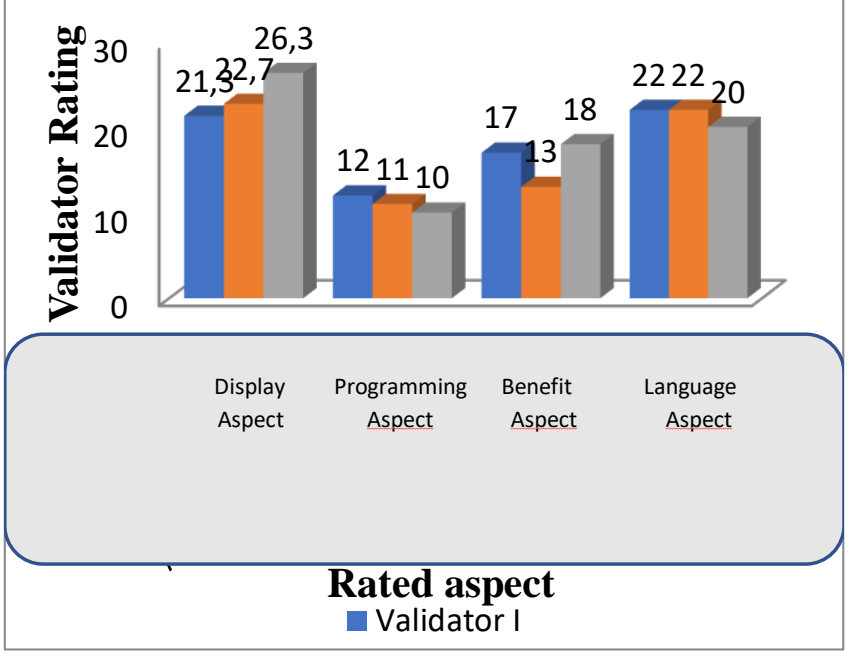

Figures 1. Graphics of Validation Assessment by Media Experts

The description of the results of the validator's assessment that has been mentioned previously shows that the display aspect and aspects, usability, and language aspects have a fairly high achievement value compared to the programming aspect so that the suggestions given by the validator are more directed to the programming aspects, namely how to interact with the media, clarity of instructions. experiment and clarity of the use of the existing buttons. According to Yuli, Yomelda and Yolli (2020: 146-154) said that one form of utilizing computer technology in physics learning is to do a practicum using the development of a Virtual Lab simulation. Virtual Laboratory is defined as a form of interactive multimedia object. Interactive multimedia objects consist of a variety of heterogeneous formats including text, hypertext, sound, images, animation, video, and graphics. Virtual Laboratory is a complex interactive multimedia object and includes a new digital form, with the aim of implicit or explicit learning so that in the development of a learning media product, several aspects that have been mentioned previously must be considered as the basis for assessing the validity of a media, in this case its usefulness aspect must be considered. by looking at the competence of students after using this media.

Virtual Lab media development assessment data by material experts obtained an average assessment of aspects of appearance, quality of learning materials, content / content, usefulness, and language aspects from 3 validators, namely $78.86 \%$ with a fairly valid validity level and categories can be used but minor revisions like the graphic below 


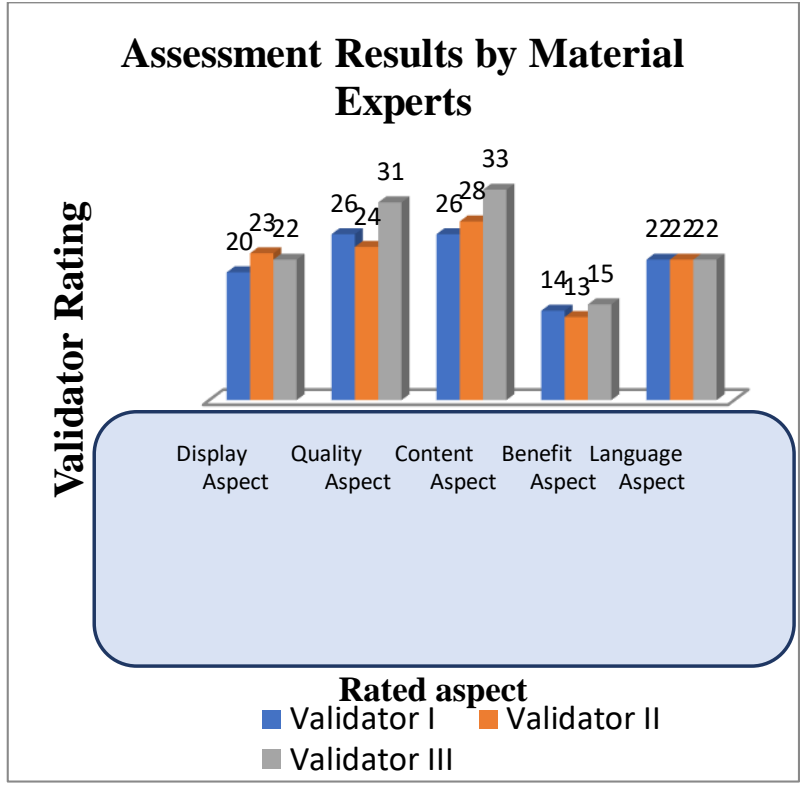

Figures 2. Graph of Validation Assessment by Material Expert

According to the description of the research results regarding the validity by media experts and material experts, the advice given includes aspects of media display in the form of writing physical formulas that must be appropriate, aspects of images on the media must be adjusted to the actual, and programming aspects by looking at the explanation of the use of simulation experiments on Virtual Lab media. and the buttons used must be clear.

The Virtual Lab learning media that has been assessed by the validator has improved both in terms of content and constructs so that it is feasible to be used in the teaching and learning process with some suggestions from the three validators. Virtual Lab learning media can be used in the teaching and learning process during the Covid-19 pandemic with distance learning so that it can improve students' critical thinking.

\subsection{Practical Results by Teachers and Students}

The level of practicality is seen from the usability and convenience of teachers, students in using and utilizing the products developed (Nieveen, 1999). The response questionnaire data that has been filled out by the three lecturers with an achievement score of $86.1 \%$ indicates that the Virtual Lab learning media developed is in the very practical category. The response data filled in by 24 students through the google form showed the achievement of a score of $82.94 \%$ which was categorized that the Virtual Lab learning media developed was in the Practical enough category while the practical response questionnaire data filled out by 46 students showed that Virtual Lab learning media that was developed with an achievement value of $77.33 \%$ which is categorized as quite practical.

The developed Virtual Lab learning media presents practicum objectives, brief theory, tools and materials, work procedures, as well as data analysis of experimental results that will be made by students independently so as to train them to also make practical reports and be able to conclude basic electrical material from the data generated. practical simulation. In accordance with what Chairani, Adeng, Ketang (2019) said which said that students can freely do practicums anywhere and anytime without the risk of lack of time, expensive costs, and tools that are difficult to find, students can also repeating mistakes made during practicum without worrying about the risks involved, so this Virtual Lab simulation technique is practically used as a learning medium to increase knowledge, think critically like actual practicum activities.

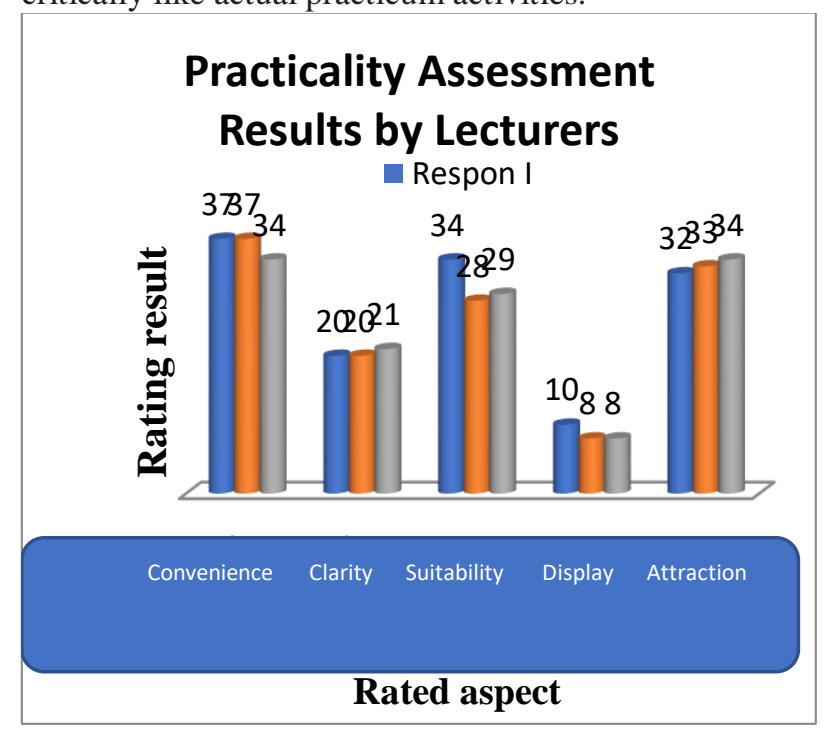

Figures 3. Teacher Practicability Rating Chart

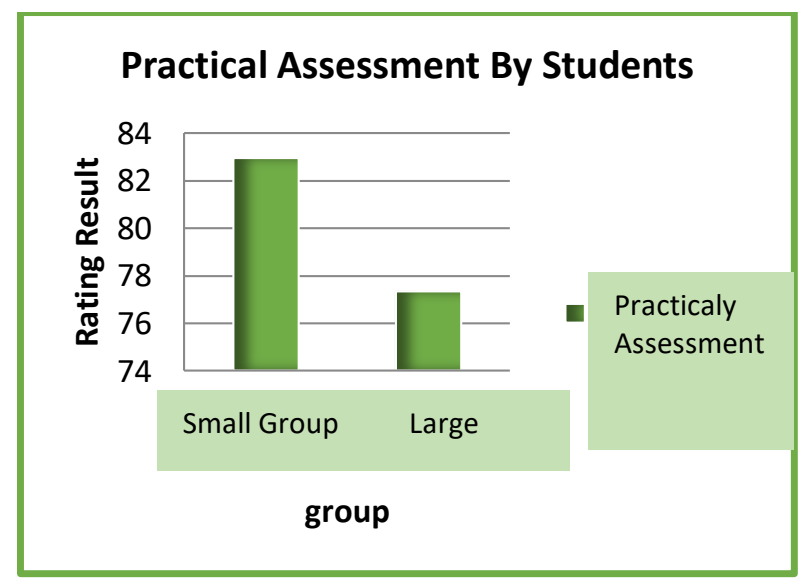

Figures 4. Graph of Practicality Assessment by Students

\subsection{Virtual Lab Effectiveness Results}

In accordance with what was said by Sepna, Zulhendri, and Gusnedi (2018:153-160) the effectiveness test can be seen from the results of the student's knowledge test. The value of students' knowledge can be done by giving pretest and posttest questions related to the material 
provided. The data to see the effectiveness in this research is in terms of pretest and posttest which are analyzed to find out also the increase in learning outcomes that can improve critical thinking after using the Virtual Lab learning media. The results of the pretest and posttest data are shown as follows:

Table 1. Average Results of Pretest and Postest Class TLB XVII

\begin{tabular}{|l|l|l|}
\hline Class & $\begin{array}{l}\text { Average Pretest } \\
\text { Value }\end{array}$ & $\begin{array}{l}\text { Average } \\
\text { Postest Value }\end{array}$ \\
\hline TLB XVII & 64.54 & 86.19 \\
\hline
\end{tabular}

Based on the $\mathrm{N}$-gain calculation, the learning outcomes of TLB XVII class students have increased which are included in the effective category, which means that the Virtual Lab learning media can help improve student learning outcomes and can improve critical thinking skills. Herman (2012:3) states that the criteria for learning are effective if they meet $3 \& 4$ effective criteria, one of which is the achievement of mastery learning outcomes, namely at least $80 \%$ classical completeness and student activities in learning using Virtual Lab media.

In accordance with what Muchson, Munzil, et al (2019: 51-64) said, virtual practicums are more efficient than physical practicums because they require a shorter time with the right results instantly. The $\mathrm{N}$-gain value generated based on the pre-test and post-test showed an increasing value according to what Ahmad, Siti Nurul Hidayah, Irsan (2014) said based on the final test, there was an increase in students' good conceptual understanding compared to before being given Virtual Laboratory media according to the data. research result.

\section{CONCLUSIONS}

From the research results, it can be concluded that the Virtual Lab Media Development with an average value of $78.76 \%$ for media validation results while $78.86 \%$ for material expert validation results, both of which are categorized as quite valid and can be used but minor revisions. Practical response of Virtual Lab Media by lecturers with an average value of $86.1 \%$ which is categorized as very practical, while by students $82.94 \%$ for small groups and $77.33 \%$ for large groups which are quite practical. The effectiveness of Media Virtual Lab shows N-Gain with a value of 0.61 which is considered effective on basic electrical materials.

\section{REFERENCES}

[1] Aisyah. 2020. Pengembangan Media Pembelajaran Berbasis Augmented Reality untuk Blended Learning pada Materi Pokok Rangkaian Listrik Searah di SMA Negeri 2 Lubuk Pakam. Tesis. Pascasarjana Universitas Negeri Medan
[2] Akbar. 2013. Instrumen Perangkat Pembelajaran. Bandung: PT Remaja Rosdakarya.

[3] Akker. 1999. Principles and Methods of Development Research. Dalam Plomp.T;Nieveen, N; Gustafson, K; Branch, R.M; dan Akker, J.V. D(eds). Design Approaches and Tools in Education and Training. London: Kluwer Academic Publisher.

[4] Arikunto. 2010. Prosedur Penelitian Suatu Pendekatan Praktek. Jakarta: Rineke Cipta

[5] Arsyad. 2013. Media Pembelajaran. Jakarta: PT. Raja Grafindo Persada.

[6] Astra, Nasbey dan Nugraha. 2015. Development of an Android Application in the Form of a Simulation Lab as Learning Media for Senior High School Students. Eurasia Journal of Mathematics, Science \& Technology Educational, 11 (5): 1081:1088

[7] Baser dan Durmus. (2010), The Effectiveness Of Computer Supported Versus Real Laboratory Inquiry Learning Environments On The Understanding Of Direct Current Electricity Among Pre-Service Elementary School Teachers. Eurasia Journal of Mathematics, Science \& Technology Education, 6(1): 47-61. ISSN: 13058223.

[8] Borg dan Gall. (1983). Educational Research, An Introduction. New York and London. Longman Inc.

[9] Chairani, Adeng dan ketang. 2019. Pengembangan Virtual Laboratory Sistem Sirkulasi pada Pembelajaran Biologi di Sekolah Menengah Atas. Jurnal Inovasi Pendidikan. 9 (1): 29-14.

[10] Chien, K.-P., Tsai, C.-Y., Chen, H.-L., Chang, W.H., \& Chen, S. (2015). Learning differences and eye fixation patterns in virtual and physical science laboratories. Computers \& Education, 82, 191201. $\quad$ http://doi.org/10.1016/j.compedu.2014.11. $\underline{023}$

[11] Costa. and Presseisen. 1985. Glossary of Thinking Skill, in A.L. Costa (ed). Developing Minds: A Resource Book for Teaching Thinking, Alexandria: ASCD.

[12] Costa. (1985). Goal for Critical Thinking Curriculum. In Costa A.L. (Ed). Developing Minds : A Resource Book for Teaching Thinking. Alexandria: Association for Supervisor and Curriculum Development (ASCD). 
[13] Gitnita, Sepna, Zulhendri Kamus, dan Gusnedi. 2018. Analisis Validitas, Praktikalitas, dan Efektifitas Pengembangan Bahan Ajar Terintegrasi Konten Kecerdasan Spiritual Pada Materi Fisika Tentang Vektor dan Gerak Lurus. Pillar of Physics Education. 11(2) : 153-160

[14] Gunawan, Ahmad Hairunnisyah. 2015. Studi Pendahuluan Pada Upaya Pengembangan Laboratorium Virtual Bagi Calon Guru Fisika. Jurnal Pendidikan fisika dan Teknologi. ISSN: $2407-6902$

[15] Herga, Grmek dan Dinevski. 2014. Virtual Laboratory As an Element of Visualization when Teaching Chemical Contents in Science Class. Journal of Education Technology, Volume 13 Issue 4.

[16] Herman. 2012. Pengembangan Perangkat Pembelajaran Model Pengajaran Langsung untuk Mengajarkan Materi Kesetimbangan Benda Tegar. Jurnal Sains dan Pendidikan Fisika. 8 (1): 1-11.

[17] Hermansyah, Gunawan, dan Lovy. 2015. Pengaruh Penggunaan Laboratorium Virtual terhadap Penguasaan Konsep dan Kemampuan Berpikiri Kreatif Siswa Pada Materi Getaran dan Gelombang. Jurnal Pendidikan Fisika dan Teknologi. 1(2):97-102.

[18] Ismail. 2016. Efektivitas Virtual Lab Berbasis STEM dalam Meningkatkan Literasi Sains Siswa dengan Perbedaan Gender. Jurnal Inovasi Pendidikan IPA, 2 (2)., 190 - 201.

[19] Ismail. 2011. Tugas Atau Soal Inovatif YangMengembangkan Kemampuan Berpikir Kritis Siswa. Prosiding Seminar Matematika Jurusan Matematika FMIPA UNESA, Surabaya. Hlm 163-173.

[20] Irvani Wulandari, Rizqi, Harlina, dan Nurmiyati. 2020. Pengembangan Media Pembelajaran Laboratorium Virtual Berbasis Discovery Learning Materi Sistem Imum Kelas XI MIPA. Jurnal Penelitian dalam bidang Pendidikan dan Pengajaran. 14(1): 61-70.

[21] Jaya, Hendra. 2012. Pengembangan Laboratorium Virtual Untuk Kegiatan Praktikum Dan Memfasilitasi Pendidikan Karakter Di SMK. Jurnal Pendidikan Vokasi. Vol 2 (1): 81-90

[22] Kuswana, Sunaryo Wowo. 2013. Taksonomi Berpikir. Bandung: PT Remaja Rosdakarya

[23] Liliasari "Peningkatan Mutu Guru dalam Keterampilan Berpikir Tigkat TinggiMelalui
Modelpembelajaran Kapita Selekta Kimia Sekolah Lanjutan", Jurnal Pendidikan Matematika dan Sains, (Edisi 3 Tahun VIII,2003), hlm. 175.

[24] Nieveen, N. 1999. Prototyping to Reach Product Quality. Dalam Plomp, T; Nieveen, N; Gustafson, K; Branch, R.M; dan Akker, J.V. D(eds). Design Approaches and Tools in Education and Training. London: Kluwer Academic Publisher.

[25] Ngurahrai Hidayah, Aisyiyah, Siska dan Nurhidayati. 2019. Pengembangan Media Pembelajaran Fisika Berbasis Mobile Learning untuk Meningkatkan Kemampuan Berpikir Kritis Peserta Didik. Jurnal Berkala Pendidikan Fisika. 12 (2)76-83.

[26] McGregor. (2007). Developing Thinking Developing Learning. Poland: Open University Press

[27] Muchson, Munzil, Betti Elgavita Winarni, Dwi Agusningtyas. 2019. Pengembangan Virtual Lab Berbasis Android Pada Materi Asam Basa Untuk Siswa SMA. Jurnal Pembelajaran Kimia. 4(1): 5164

[28] Munandar. 2009. Pengembangan Kreativitas Anak Berbakat. Jakarta: Rineka Cipta. Pehkonen, Erkki. 1997. The state of art in mathematical creativity. Zentralblatt fur Didaktik de Mathematik, 29(3),6367

[29] Prasetiyo. (2017). Pengembangan Buku Ajar Berbasis Lingkungan Hidup pada Materi Kuliah Biologi di Universitas Tribhuwan Tunggadewi. Jurnal Pendidikan Biologi Indonesia. 3(1): 19- 27

[30] Rahmat. 2013. Statistika Penelitian. Bandung: Pustaka Setia.

[31] Rochmad. 2012. Desain Model Pengembangan Perangkat Pembelajaran Matermatika. Jurnal Kreano, 3(1), 59-72

[32] Romeois. 2015. Berpikir Kritis. [online]. (http://dokumen.tips_berpikirkritis55949315983b6, diakses 11 April 2017).

[33] Siswono, Hendrik. 2016. Pengaruh Problem Based Learning Berbantuan Kombinasi Real Dan Virtual Laboratory Terhadap Keterampilan Proses Sains Dan Penguasaan Konsep Siswa Di Sman 1 Lumajang. Jurnal Riset Pendidikan Fisika. Vol 1 (1) : 5-16

[34] Sapriya (2011). Pendidikan IPS. Bandung: PT Remaja Rosdakarya 
[35] Siti Khabibah, Pengembangan Media Pembelajaran Matematika dengan Soal Terbuka untuk Meningatkan Kreativitas Peserta didik Sekolah Dasar, (Program Pasca Sarjana UNESA: 2006), hal. 15

[36] Slavin.1994. Model Pembelajaran Cooperatif Script. Jakarta: Airlangga.

[37] Sugiyono 2009. Metode Penelitian Pendidikan Pendekatan Kuantitatif, Kualitatif, dan R \& D. Bandung : Alfabeta.

[38] Siregar, B., Suripto, B., Hapsoro, D., Lo, E. W., \& Sugiyono, F. (2015). Metode Penelitian Kombinasi (Mix Methods). Bandung: Alfabeta.

[39] Sukmadinata, Nana Syaodih. 2008. Metode Penelitian Pendidikan. Bandung: Remaja Rosdakarya.

[40] Suyitno.2013. Keefektifan Penerapan model Pembelajaran (online). Tersedia: http://pinggirlaras.blogspot.com/2010/06/.

Keefektifan Penerapan model Pembelajaran.html. (Januari 2019).

[41] Swandi, Ahmad, Siti dan Irsan. 2014. Pengembangan Media Pembelajaran Laboratorium Virtual untuk Mengatasi Miskonsepsi pada Materi Fisika Inti di SMAN 1 Binamu Jeneponto. Jurnal Fisika Indonesia.18(52) ISSN:1410-2994.

[42] Wahyuni, Sudarisman, dan Karyanto. 2013. Pembelajaran Biologi Model Poe (Prediction Observation, Explanation) melalui Laboratorium Rill dan Laboratorium Virtuil di tinjau dari Aktivitas Belajar dan Kemampuan Berpikir Abstrak. Jurnal Inkuiri. 2 (3): 269-278.

[43] Wibowo, Suhandi, Rusdiana, Darman, Ruhiat, Denny, Suherman dan Fatah. 2016. Microscopic Virtual Media (MVM) in Physics Learning: Case Study on Students Understanding of Heat Transfer. Journal of Physics: Conference series 739; 1-6

[44] Wijaya, Cece. 2010. Pendidikan Remidial. Bandung: Remaja Rosdakarya.

[45] Yanti, Yuri, Yumelda dan Yolli. 2020. MetaAnalisis Pengaruh Media Virtual Laboratory dalam Pembelajaran Fisika terhadap Komptensi Siswa. Jurnal Penelitian dan Pembelajaran Fisika. 6(2): 146-154.

[46] Yuniarti, Dewi, dan Susanti. 2012. Pengembangan Virtual Laboratory Sebagai Media Pembelajaran Berbasis Komputer Pada Materi Pembiakan Virus. Jurnal Pendidikan Biologi Unnes. 1(1): 28
[47] Zulhelmi, Adlim, dan Mahidin. 2017. Pengaruh Media Pembelajaran Interaktif terhadap Peningkatan Keterampilan Berpikir Kritis Siswa. Jurnal Pendidikan Sains Indonesia. 5(1): 72-80. 